Kazuhiro Tsukamoto • Hideo Yoshida

Shuichiro Watanabe · Takao Suzuki • Mariko Miyao

Takayuki Hosoi · Hajime Orimo • Mitsuru Emi

\title{
Association of radial bone mineral density with CA repeat polymorphism at the interleukin 6 locus in postmenoposal Japanese women
}

Received: October 21, 1998 / Accepted: December 15, 1998

\begin{abstract}
Twin studies have shown strong correlations between bone mass and genetic factors. Some of the genes involved could regulate bone metabolism and bone formation and resorption, all processes that determine bone mass. One candidate gene, interleukin 6 (IL-6), has been implicated in the pathogenesis of bone loss because it stimulates osteoclasts. We investigated a possible association between the CA repeat polymorphism at the $I L-6$ gene locus and the bone mineral density (BMD) of radial bone in 472 postmenopausal Japanese women. Genotypes were classified into six groups according to the number of CA repeats present, from 13 to 18 . BMD was expressed as adjusted BMD, which was the body mass index (BMI)- and age-adjusted average BMD. The 73 women who possessed an A1 allele (134 bp, containing 18 repeats of $\mathrm{CA}$ ) had significantly lower adjusted BMD than those participants $(n=399)$ who did not carry an allele of that size (mean $\pm \mathrm{SD}$ values, $0.294 \pm 0.064$ vs $0.312 \pm$ $\left.0.061 \mathrm{~g} / \mathrm{cm}^{2} ; P=0.0221\right)$. This result suggests that genetic variation at the $I L-6$ gene locus is associated with some determinants of BMD in postmenopausal women.
\end{abstract}

Key words Interleukin 6 - Bone mineral density - Osteoporosis $\cdot$ Association study $\cdot$ Microsatellite marker

\section{Introduction}

The reduction in bone mass per unit volume that is characteristic of osteoporosis is not accompanied by any qualita-

K. Tsukamoto $\cdot$ M. Emi $(\Delta)$

Department of Molecular Biology, Institute of Gerontology, Nippon

Medical School, 1-396 Kosugi-cho, Nakahara-ku, Kawasaki 211-8533, Japan

Tel. +81-44-733-5230; Fax +81-44-733-5192

e-mail: memi@nms.ac.jp.

H. Yoshida $\cdot$ S. Watanabe $\cdot$ T. Suzuki

Tokyo Metropolitan Institute of Gerontology and Hospital, Tokyo,

Japan

M. Miyao $\cdot$ T. Hosoi $\cdot$ H. Orimo

Department of Geriatrics, Faculty of Medicine, University of Tokyo,

Tokyo, Japan tive abnormalities in bone mineral content or the organic matrix. This indicates that the rate of bone resorption must exceed that of bone formation, and, in fact, the rate of bone formation tends to be lower than normal in patients with osteoporosis, particularly in women after menopause. However, the degree of reduction varies among postmenopausal women, ranging from "normal" to "rapid". As twin studies have shown strong correlations between bone mass and genetic factors (Pocock et al. 1987; Slemenda et al. 1991), it follows that some of the genes in question are likely to act as regulators of bone formation or resorption. Therefore the heterogeneity in bone mass may reflect genetic variations within the population.

Calcium levels in serum are maintained in homeostasis through balanced interactions among calcitonin, parathyroid hormone, vitamin D, steroid hormones, and cytokines, and their receptors and modulators. One of the most likely candidates for determining bone mass is interleukin 6 (IL6). $I L-6$ is a pleiotropic cytokine that has also been called interferon beta-2 (IFNB2), B-cell differentiation factor (BSF2), hepatocyte stimulatory factor (HSF), and hybridoma growth factor (HGF), according to the biological activities by which this peptide was identified by independent researchers (Zilberstein et al. 1986, Hirano et al. 1986, Sehgal et al. 1987). IL-6 has been implicated in the pathogenesis of bone loss because the gene product stimulates osteoclasts. To investigate a possible relationship between genetic variation at the human $I L-6$ locus and osteoporosis, we determined the genotypes of a large panel of Japanese women at this polymorphic locus, and correlated their genotypes with bone mineral density.

\section{Subjects and methods}

Subjects

DNA samples were obtained from the peripheral blood of 472 postmenopausal Japanese women living in the rural Akita area, whose ages ranged from 66 to 92 years (mean, 
$73.2 \pm 5.8$ years). All were non-related volunteers and gave their informed consent prior to the study. No participant had medical complications or was undergoing treatment for conditions known to affect bone metabolism, such as pituitary disease, hyperthyroidism, primary hyperparathyroidism, renal failure, adrenal disease, or collagen disease, and none was receiving estrogen replacement therapy.

Measurement of bone mineral density (BMD)

The BMD of radial bone (expressed in $\mathrm{g} / \mathrm{cm}^{2}$ ) of each participant was measured by dual-energy X-ray absorptiometry (DPX-L; Lunar, Madison, WI, USA). This parameter was recorded as the adjusted BMD, to correct for differences in age, height, and weight. The formulas used were:

$$
\begin{aligned}
& \text { Body mass index }(\mathrm{BMI}) \\
& \quad=(\text { body weight })(\mathrm{kg}) /(\text { body height })^{2}(\mathrm{~m}) \\
& \text { Adjusted BMD }=\text { BMD }-0.0052432908 \\
& \times(73.1716102-\text { age })+0.0088382998 \\
& \times(23.2271299-\text { BMI })(\text { Kleinbaum et al. 1988) }
\end{aligned}
$$

Determination of microsatellite polymorphism by polymerase chain reaction (PCR)

Each PCR amplification of the CA repeat polymorphism at the IL6 locus was performed in a volume of $10 \mu l$ containing $20 \mathrm{ng}$ of genomic DNA obtained from peripheral blood, $10 \mathrm{mM}$ of Tris $\mathrm{HCl}(\mathrm{pH} 8.4), 50 \mathrm{mM}$ of $\mathrm{KCl}, 1.5 \mathrm{mM}$ of $\mathrm{MgCl}_{2}, 0.01 \%$ gelatin, $200 \mu \mathrm{M}$ of dNTP, $2.5 \mathrm{pmol}$ of $\left[{ }^{32} \mathrm{P}\right]$ end-labeled IL6.6F and of non-labeled IL6.7R (Tsukamoto et al. 1998a), and 0.25 units of Taq polymerase. Cycle conditions were $94^{\circ} \mathrm{C}$ for $4 \mathrm{~min}$, then 30 cycles of $94^{\circ} \mathrm{C}$ for $30 \mathrm{~s}$, $65^{\circ} \mathrm{C}$ for $30 \mathrm{~s}$, and $72^{\circ} \mathrm{C}$ for $30 \mathrm{~s}$, with a final extension step of $5 \mathrm{~min}$ at $72^{\circ} \mathrm{C}$, in a Gene Amp PCR9600 System (Perkin Elmer Cetus, Norwalk, CT, USA). The PCR products were electrophoresed for $2 \mathrm{~h}$ at $2000 \mathrm{~V}$ in 0.3 -mm-thick denaturing $6 \%$ polyacrylamide gels containing $36 \%$ formamide and $8 \mathrm{M}$ urea. The gels were transferred to filter papers, dried at $-80^{\circ} \mathrm{C}$, and autoradiographed. The size of each allele was determined by comparison with a sequencing ladder of control DNAs (Tsukamoto et al. 1998a).

\section{Statistical analysis}

Adjusted BMD values were compared in individuals who possessed one allele of a given genotype and individuals who did not, using non-parametric (Student-NewmanKeuls) analysis. Differences in means were considered statistically significant for $P$ values $<0.05$.

\section{Results}

The 472 postmenopausal Japanese women in our panel were genotyped for the CA repeat polymorphism at the $I L$ -
6 locus. The polymorphic PCR products had been classified into six alleles; A1 (134bp, 18 CA repeats) to A6 (124bp, 13 CA repeats) The distribution of the six alleles in this population is shown in Fig. 1. The distribution among these women living in the rural Akita area was similar to that observed previously in the general Japanese population (Tsukamoto et al. 1998a).

We sought to correlate genotype(s) at the $I L-6$ microsatellite locus with the adjusted BMD of radial bone. The 73 women who possessed the A1 allele (134bp, 18 repeats) showed significantly lower adjusted BMD values than those women $(n=399)$ without this allele (mean \pm $\mathrm{SD}, 0.294 \pm 0.064$ vs $0.312 \pm 0.061 \mathrm{~g} / \mathrm{cm}^{2} ; P=0.0221$ ) (Table 1). Figure 2 shows the lowering effect on adjusted BMD of the A1 allele at the $I L-6$ locus.

The background data of the groups with and without the A1 allele are summarized in Table 1 . We found no significant differences between the two groups in mean age, height, or weight. Of the 73 women possessing the A1 allele,

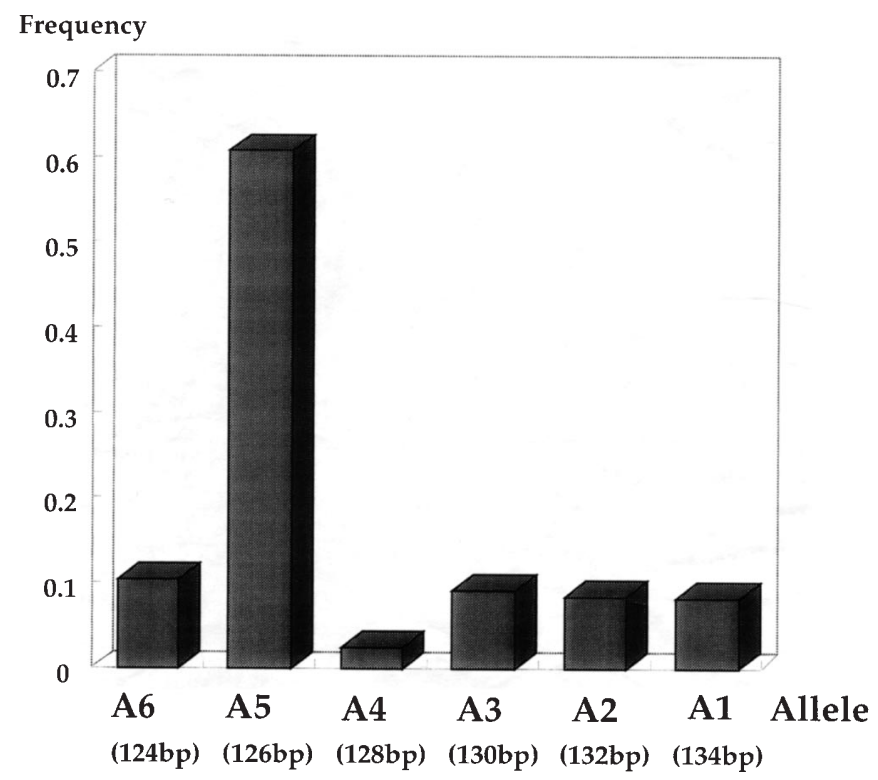

Fig. 1. Frequency distribution of alleles containing the CA repeat polymorphism at the interleukin-6 (IL)-6 gene locus in 472 postmenopausal Japanese women

Table 1 Comparison of age, body height, and weight in Japanese postmenopausal women with and without a 134-bp allele at the $I L-6$ gene locus

\begin{tabular}{lccl}
\hline & $\begin{array}{l}\text { 134-bp } \\
\text { allele }(+) ; \\
n=73\end{array}$ & $\begin{array}{l}\text { 134-bp } \\
\text { allele }(-) ; \\
n=399\end{array}$ & $\begin{array}{l}\text { Statistical } \\
\text { significance }\end{array}$ \\
\hline Age (years) & $72.3 \pm 5.1$ & $73.3 \pm 5.9$ & NS \\
Body height $(\mathrm{cm})$ & $145.0 \pm 5.8$ & $144.8 \pm 6.1$ & NS \\
Body weight $(\mathrm{kg})$ & $48.4 \pm 6.9$ & $49.7 \pm 8.7$ & $\mathrm{NS}$ \\
ADJBMD $(\mathrm{g} / \mathrm{cm})$ & $0.294 \pm 0.064$ & $0.312 \pm 0.061$ & $P=0.0221$ \\
\hline
\end{tabular}

NS, Not significant; IL, interleukin; ADJBMD, mean adjusted bone mineral density (see text for explanation) 


\section{IL6}
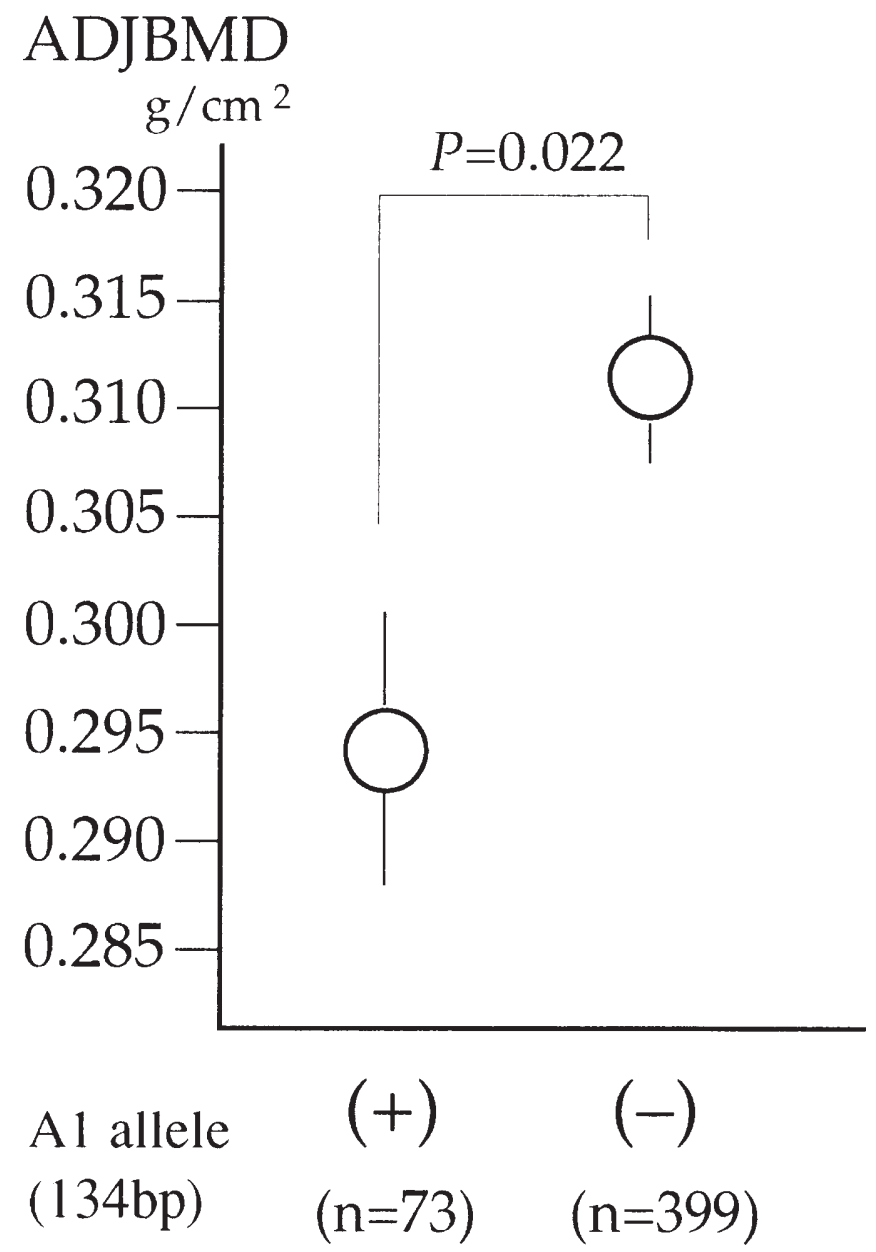

Fig. 2. Comparison of mean adjusted bone mineral density $(A D J B M D)$ of radial bone in the group of individuals that carried an A1 allele $(+)$ and the group that did not $(-)$

5 were homozygous at this locus. However, no significant differences in adjusted BMD were detected between women who were homozygous for the A1 allele and those who were heterozygous (data not shown).

\section{Discussion}

Interleukin 6 is a multifunctional cytokine essential to the regulation of bone resorption, as well as the immune response and hematopoiesis. It exerts its actions through binding to its cell-surface receptor, IL6 receptor. As IL-6 and its receptor stimulate osteoclast development and, thereby, the process of bone resorption, they are pathogenic factors in bone loss, especially that triggered by an estrogen-deficiency state (Manolagas et al. 1995).
Osteoclast activity is essential for bone remodeling, and imbalances in the regulation of this process may lead to metabolic bone diseases. Postmenopausal osteoporosis is a common disease that is due to increased osteoclast activity. In particular, overproduction of IL-6 has been implicated in osteoporotic bone loss (Manolagas et al. 1995). IL-6 is a nuclear factor kappa-beta (NFKB)-regulated gene, and its activation is blocked by the estrogen receptors in an NFKB-dependent way. In this connection, it is intriguing that NFkappaB-knockout mice developed osteopetrosis because of a defect in osteoclast differentiation (Iotsova et al. 1997).

For the study reported here, we genotyped a large panel of postmenopausal Japanese women at a newly isolated microsatellite at the $I L-6$ locus. One genotype, A1 (134bp, 18 CA repeats) was associated with lower BMD in these women. The data presented here suggest that variations or some mutations in or adjacent to the $I L-6$ gene may affect bone metabolism and eventually cause variations in BMD. The postmenopausal Japanese women in our panel who carried the A1 allele at the $I L-6$ locus showed lower adjusted BMD than those who carried only alleles of other sizes. Lowered BMD in postmenopausal women could be a result of abnormally rapid bone loss and/or lower peak bone mass that had occurred when they were young adults. To clarify these issues it will be necessary to carry out a further genetic study or to investigate the genomic structure of the entire region containing the $I L-6$ gene and its control elements in affected individuals.

Investigations of genetic variations in humans have been attempted at the vitamin $\mathrm{D}$ receptor locus (Morrison et al. 1994), the estrogen receptor alpha / beta loci (Sano et al. 1995; Kobayashi et al. 1996, Tsukamoto et al. 1998b), the matrix Gla protein locus (Watanabe et al. 1998), and the collagen type I alpha 1 locus (Grant et al. 1996) to determine their role in bone metabolism. Murray et al. (1997) studied the relationship of $I L-6$ polymorphism to BMD in women living in the northeast of Scotland; their results were similar for menopausal and post-menopausal women. The $3^{\prime}$ flanking polymorphism targeted in their study lies within $110 \mathrm{~kb}$ of the polymorphism targeted in the present study. Murray et al. measured BMD at the lumbar spine, a useful method for measuring bone mass in younger women. We measured BMD at the radius, following the 1995 Guidelines for Osteoporosis Screening in a Health Check-up Program for the Elderly conducted by the Ministry of Health and Welfare of Japan. This method was recommended for BMD measurement in elderly people, who often have osteoarthritis of the spine. Given that our results in postmenopausal Japanese women are similar to those of Murray et al., we suggest that the polymorphic microsatellite at the $I L-6$ locus may be a useful marker for predicting future bone loss and for allowing early therapeutic intervention in women at high risk of osteoporosis.

Acknowledgments We thank Mr. Ken Haruta and Miss Ikuyo Watanabe for their technical assistance.

This work was supported in part by a grant for an osteoporosis project from the Ministry of Health and Welfare of Japan, and by a grant from the Novartis Foundation for Gerontological Research. 


\section{References}

Grant SFA, Reid DM, Blake G, Herd R, Fogelman I, Ralston SH (1996) Reduced bone density and osteoporosis associated with a polymorphic $\mathrm{Sp} 1$ site in the collagen type I alpha 1 gene. Nature Genet 14: 203-205

Hirano T, Yasukawa K, Harada H, Taga T, Wataqnabe Y, Matsuda T, Kashiwamura S, Nakajima K, Koyama K, Iwamatsu A, Tsunasawa S, Sakiyama F, Matsui H, Takahara Y, Taniguchi T, Kishimoto T (1986) Complementary DNA for a novel human interleukin (BSF-2) that induces B lymphocytes to produce immunoglobulin. Nature 324 : 73-76

Iotsova V, Caamano J, Loy J, Yang Y, Lewin A, Bravo R (1997) Osteopetrosis in mice lacking NFkappaB1 and NFkappaB2. Nature Med 3: $1285-1289$

Kleinbaum DG, Kupper LL, Muller KE (1988) Applied regression analysis and other multivariate methods, 2nd edn. PWS-KENT Publishing, Boston, pp 299--301

Kobayashi S, Inoue S, Hosoi T, Ouchi Y, Shiraki M, Orimo H (1996) Association of bone mineral density with polymorphism of the estrogen receptor gene. J Bone Miner Res 11: 306-311

Manolagas SC, Bellido T, Jilka RL (1995) New insights into the cellular, biochemical, and molecular basis of postmenoposal and senile osteoporosis: Role of IL-6 and gp130. Int J Immunopharmacol 17: 109-116

Morrison NA, Qi JC, Tokita A, Kelly PJ, Crofts L, Nguyen TV, Sambrook PN, Eisman JA (1994) Prediction of bone density from vitamin D receptor alleles. Nature 367: 284-287
Murray RE, McGuigan F, Grant SFA, Reid DM, Ralston SH (1997) Polymorphisms of the interleukin- 6 gene are associated with bone mineral density. Bone 21: 89-92

Pocock NA, Eisman JA, Hopper JL, Yeates MG, Sambrook PN, Eberl S (1987) Genetic determinants of bone mass in adults. A twin study. J Clin Invest 80: 706-710

Sano M, Inoue S, Hosoi T, Ouchi Y, Emi M, Shiraki M, Orimo H (1995) Association of estrogen receptor dinucleotide repeat polymorphism with osteoporosis. Biochem Biophys Res Commun 217: 378-383

Sehgal PB, May LT, Tamm I, Vilcek J (1987) Human beta-2 interferon and B cell differentiation factor BSF-2 are identical. Science 235: 731-732

Slemenda CW, Christian JC, Williams CJ, Norton JA, Johnston CC Jr. (1991) Genetic determinants of bone mass in adult women: A reevaluation of the twin model and the potential importance of gene interaction on heritability estimates. J Bone Miner Res 6: 561-567

Tsukamoto K, Haruta K, Shiba T, Emi M (1998a) Isolation and mapping of a polymorphic CA repeat sequence at the human interleukin 6 locus. J Hum Genet 43: 71-72

Tsukamoto K, Inoue S, Hosoi T, Orimo H, Emi M (1998b) Isolation and radiation hybrid mapping of dinucleotide repeat polymorphism at the human estrogen receptor beta locus. J Hum Genet 43: 73-74

Watanabe I, Tsukamoto K, Shiba T, Emi M (1998) Isolation and radiation hybrid mapping of dinucleotide repeat polymorphism at the human matrix Gla protein (MGP) locus. J Hum Genet 43: 75-76

Zilberstein A, Ruggieri R, Korn JH, Revel M (1986) Structure and expression of cDNA and genes for human interferon-beta-2, a distinct species inducible by growth-stimulatory cytokines. EMBO J 5: 2529-2537 